\title{
Variation of protease activity in coconut kernel in relation to variety, nut maturity and season
}

\author{
Panicker, L.M. ${ }^{1}$, Usha, R. ${ }^{2}$ and Mandan, C.N. ${ }^{3}$
}

\begin{abstract}
Studies on the presence and involvement of proteases in the development and maturation of endosperm of Cocos nucifera L. revealed changes in concentration of proteases with the age of the nut, variety and season. More BAPNA ( N $\alpha$ - Benzoyl DL arginine p-nitroanilide) hydrolysing activity. Was observed at the immature stage and more gelatinolytic activity at the mature stage of the coconut endosperm development. There was apparent difference between seasons, the highest protease activity was during winter months.
\end{abstract}

Key words: Protease activity, seasonal variation, Cocos nucifera, coconut kernel development, BAPNA (N $\alpha$ - Benzoyl DL- arginine p-nitroanilide).

${ }^{1}$ Central Plantation Crops Research Institute (Regional Station), Kayamkulam, Krishnapuram P.O.-690533, Kerala, India. Email: leela_iicb@yahoo.com 


\section{Introduction}

Proteases (proteolytic enzymes or proteinases) refer to a major group of enzymes specialized to catalyze the hydrolysis of peptide bonds in a highly specific manner by which large protein molecules are cleaved into smaller peptides as and when it is needed. They are part and parcel of every metabolic activity in the cell and there by it controls the vital activities of all living organisms. It functions in a variety of peptide and protein processing events and regulates the process of total protein turn over in the body. Activities of the proteases are responsible for the generation of the peptides that act as hormones and antibodies. Proteases have a plethora of essential functions in the physiology and development of plants. Seed maturation is a subject of great passion for researchers who are involved in elucidating the molecular mechanisms fundamental to proteolysis. Different biochemical phenomena, such as processing of precursor proteins, regulation of key enzymes and proteins needed for development through proteolysis, removal of unwanted proteins and overall process of protein turnover are carried out by a number of different types of proteases. Though coconut is a widely studied palm the involvement of proteases during endosperm development and maturation has not been reported. Proteolytic activity in the haustorium (Nagarajan et al., 1963) and the activity profile of the proteases during coconut germination (Balasubramanian et al., 1973; Manjula et al., 1993) were the only few reports regarding the presence of protease activity in coconut. Hence, this investigation was taken up to study the extent of protease involvement as well as its variation with the maturity.

\section{Materials and methods}

The present study was taken up in the Drug Design, Development and Molecular Modeling Lab, Indian Institute of Chemical Biology (IICB), Kolkata, India. Coconuts were collected from the Jadavpur market, IICB campus and from the identified palms of Central Plantation Crops Research Institute (Regional station)
Kayamkulam, Kerala. Coconuts at different stages of maturity were procured from a single palm at IICB. Varieties investigated were West Coast Tall (WCT), Choughat Green Dwarf (CGD), Choughat Green Orange (CGO), Laccadive Micro, Spikata, Hybrid DxT and Hybrid TxD. Crude extract of the coconut kernel was prepared in four volumes of ice cold 20mM Tris saline buffer $\mathrm{pH} 7.8$, homogenate after straining through the muslin cloth was centrifuged at $14,400 \mathrm{~g}$ for 25 minutes at $4^{0} \mathrm{C}$ and the supernatant solution was filtered through glass wool after the removal of the creamy layer. Protein was estimated by using Coomassie blue dye-binding assay using BSA as the standard (Bradfords, 1976) and also monitored spectro-photometrically by quantitating its absorbance at $280 \mathrm{~nm}$. Protease activity of the extract was assayed using the synthetic peptide BAPNA as the substrate. The reaction was carried out at $37^{\circ} \mathrm{C}$ for $1 \mathrm{hr}$. The reaction mixture contained $50 \mu \mathrm{l}$ of crude extract, $100 \mathrm{mM}$ Tris $\mathrm{Hcl} \mathrm{pH} 8.5$ and $0.5 \mathrm{mM}$ BAPNA in a total volume of $500 \mu$. The coloured $p$-nitroaniline liberated was measured at $405 \mathrm{~nm}$ using spectrophotometer (Hitachi, 2000). One unit of enzyme activity (EU) is expressed as $1 \mu$ mole of p-niroaniline liberated per hour under the conditions of assay. The enzyme activity was calculated using the molar extinction coefficient of $p$-nitroaniline as 10,500 $\mathrm{M}^{-1} \mathrm{~cm}^{-1}$ at $405 \mathrm{~nm}$. Three separate sets of experiments were carried out in duplicates for each group of analysis. SDS/PAGE zymogram analysis for the detection of proteases was done by using $0.25 \%$ gelatin incorporated $12 \%$ poly acrylamide gel as described by Heussen and Dowdle (1980).

\section{Results and discussion}

Protease activity in developing nuts was carried out using BAPNA as the synthetic substrate at different stages of seed maturity. The BAPNA hydrolysing activity was more during the immature stage and it decreased with increasing age of the kernel (Table 1). As shown in the table, we observed a 4.3 fold increase in 
the total protein content as the seed matured from 6-7 months to 12 months. When the proteolytic activity was analysed using SDS/PAGE zymogram, activity was observed only in the fully mature coconut kernel extract (Fig. 1). These two results followed an opposing pattern. In the zymogram analysis, the different proteins in the extract got separated according to the molecular weight and the zones of hydrolysis were formed as a result of gelatin cleavage by a single polypeptide of protease where the interference by endogenous substrate is absent. Absence of cleavage zones or bands prior to maturation may be due to the insufficient amount of enzymes in the immature kernels to generate a clear zone. Decreased BAPNA hydrolysis during the course of maturation may be due to the increase in the endogenous protein substrate competing with the synthetic substrate as there is an enrichment of the protein content with advancing maturity. Among the protease profiles of different varieties of fully matured coconuts, WCT showed a highest value (Table 2). SDS/PAGE analysis of proteolytic activity showed more intense bands for the variety 'spikata' (Fig. 2). Though the proteases were present in coconut through out the year, apparently there was a difference in the enzyme profile with seasonal variation, the highest protease activity found during winter (Fig. 3).

Table 1. Protein and the BAPNA hydrolysing activity profiles during endosperm maturation in coconut

\begin{tabular}{|c|c|c|}
\hline $\begin{array}{c}\text { Approximate age of } \\
\text { the coconut from } \\
\text { the date of } \\
\text { flowering (months) }\end{array}$ & $\begin{array}{c}\text { Protein in } \\
\text { kernel } \\
\mathrm{mg} / \mathrm{g}\end{array}$ & $\begin{array}{c}\text { Enzyme } \\
\text { activity } \\
\text { in kernel } \\
\mathrm{EU} / \mathrm{g}\end{array}$ \\
\hline $6-7$ & 3.84 & 1.47 \\
\hline $8-9$ & 7.14 & 0.87 \\
\hline $10-11$ & 11.25 & 0.58 \\
\hline 12 & 16.5 & 0.51 \\
\hline
\end{tabular}

Protein content as well as BAPNA hydrolyzing activity per gram kernel of different stages of coconut maturity was calculated as described in the methods section. Results shown here are out of three experiments carried out in duplicates. Each value represents mean of three coconuts harvested from the same bunch.
Table 2. Enzyme activity of different varieties of fully matured coconuts

\begin{tabular}{|l|c|}
\hline \multicolumn{1}{|c|}{ Name of coconut variety } & $\begin{array}{c}\text { Enzyme activity } \\
\text { (E.U/g kernel) }\end{array}$ \\
\hline Coconut from IICB & 0.58 \\
\hline West Coast Tall (WCT) & 0.72 \\
\hline Chowghat Green Dwarf (CGD) & 0.56 \\
\hline Chowghat Orange Dwarf (COD) & 0.38 \\
\hline Laccadive Micro & 0.58 \\
\hline Spikata & 0.46 \\
\hline Dwarf x Tall (DXT) & 0.66 \\
\hline Tall x Dwarf (TXD) & 0.44 \\
\hline
\end{tabular}

BAPNA hydrolying activity per gram kernel of different coconut variety was calculated as described in the method section. Results shown here are out of 3 experiments carried out in duplicate. An average value of three nuts from each variety is shown here. Each value represents mean of three coconuts from each variety.

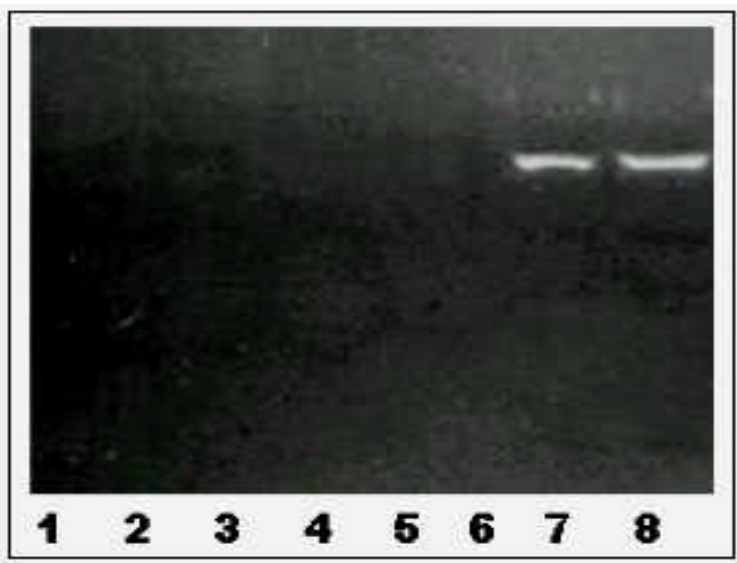

Fig. 1. SDS/PAGE zymogram analysis of gelatinolytic activity during endosperm development (Equal volumes $(5$ and $10 \mu \mathrm{l})$ of the endosperm extract prepared in 4 volumes of 50mM Tris- $\mathrm{HCl}, \mathrm{pH}-6.8$ were subjected to SDS-PAGE zymogram analysis Lanes were loaded with extracts of endosperm of different stages of development. Lanes: 1, 2-(6-7) month old; 3, 4-(8-9) month old; 5, 6-(10-11) month old and 7, 8-(fully matured-12) month old coconuts). 


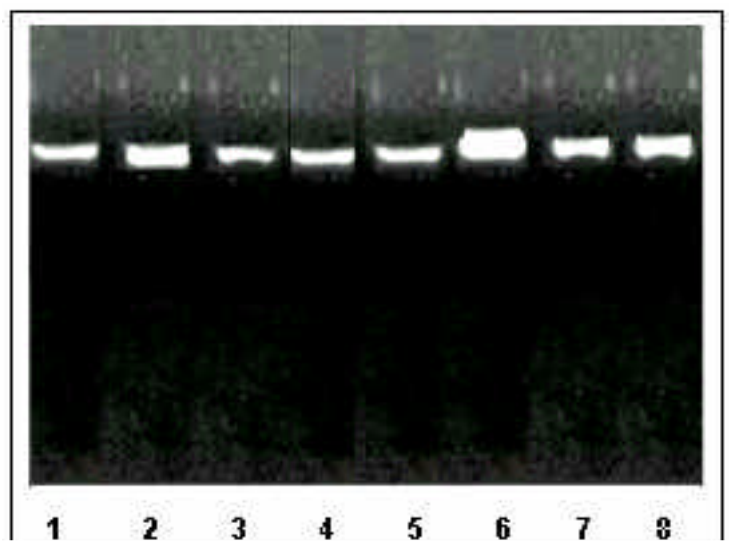

Fig. 2. SDS/PAGE zymogram analysis of gelatinolytic activity of endosperm of different varieties of coconuts (Equal volumes of the extracts were subjected for SDS/PAGE zymogram analysis on $12 \%$ polyacrylamide gels. Lanes (1-8): Coconut from local market, WCT, CGD, CGO, Laccadive Micro, Spikata, Hybrid DxT, Hybrid TxD).

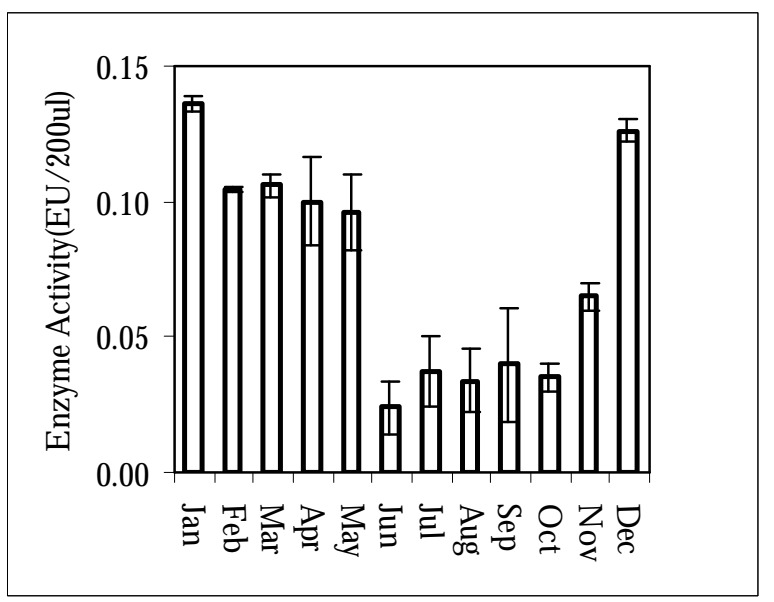

Fig. 3. Seasonal variation in the BAPNA hydrolyzing activity of coconut kernel (The BAPNA hydrolysis by the kernel extract of coconuts matured during each month of the year was compared. An average of the three consecutive years are shown above. Values represent mean \pm SEM).

It can be inferred that the developmental mechanism involving proteolysis remained the same irrespective of the age, colour, size or physical appearance of the nut with a difference in the concentration of the enzyme. Enzyme profile for the three consecutive years represented the effect of climate and the observed changes might be the adaptation of the plant to overcome the unfavourable situation.

BAPNA hydrolysing activity as well as the position and intensity of the proteolytic band of coconut kernel extracted from Kolkata as well as the varieties brought from Kerala were in good agreement with each other.

\section{Conclusion}

The changes in the proteolytic activities during seed maturation provide some insights into the mechanism of protein mobilization that takes place during seed development. Seed development is marked by the synthesis of various proteins and this process involves specific protein processing steps, during which the participation of proteases plays an important role. The developmental profile of total protein during development shows a steady increase and the increased activity of proteases during early development can be better dealt from the background that the proteases might play a vital role in the processing of proteins. Even though, the mature seeds apparently observe as dormant, the essential cellular metabolism involving protein turn over occurs regularly and thus the presence of proteases in the matured coconut impart a significant task of protein degradation. Observed variations during the various periods of the year might be the adaptation to overcome the changing environment. Appreciable differences between varieties were not observed in spite of vide geological distribution.

\section{Acknowledgement}

The authors gratefully acknowledge Dr. K.P. Mohanakumar (Head, Neurochemistry), Dr. S.K. Datta and Shri. Samir Roy of IICB, Kolkata for their valuable help. Thanks are due to Dr. R.V. Nair, Principal Scientist, CPCRI for sparing the marked nuts to carry out this study. 


\section{References}

Balasubramanian, K., Atukorala, T.M.S., Wijesundara, S. and Hoover, A.A. 1973. Biochemical changes during germination of coconut. Ann. Bot. 37: 439-445.

Bradford, M.M. 1976. A rapid and sensitive method for the quantitation of microgram quantities of protein utilizing the principle of protein-dye binding. Analyt. Biochem. 72: 248-254.

Laemmli, U.K. 1970. Cleavage of structural proteins during the assembly of the head of Bacteriophage T4. Nature 227: 680-685.

Manjula, C., Chempakam, B. and Rajagopal, V. 1993. Physiological and biochemical changes during the germination of coconut seeds. J. Plant. Crops 21 (supplement): 313-321.

Nagarajan, M. and Pandalai, K.M. 1963. Studies on the enzyme activity in the haustorium of germinating coconut. Indian Cocon. J. 17: 25-34.

Heussen, C. and Dowdle, E.B. 1980. Electrophoretic analysis of plasminogen activators in polyacrylamide gels containing sodium dodecyl sulfate and copolymerised substrates. Analyt. Biochem. 102: 196-202. 